\title{
Nectarine Fruit Ripening and Quality Assessed Using the Index of Absorbance Difference $\left(I_{\mathrm{AD}}\right)$
}

\author{
E. Bonora, ${ }^{1}$ D. Stefanelli, ${ }^{2}$ and G. Costa ${ }^{1}$ \\ ${ }^{1}$ Department of Agricultural Sciences, 46 Via Fanin, 40127 Bologna, Italy \\ ${ }^{2}$ Department of Primary Industries, Knoxfield Centre, Private Bag 15, 621 Burwood Highway, Ferntree Gully 3156, Australia
}

Correspondence should be addressed to E. Bonora; elisa.bonora4@unibo.it

Received 30 January 2013; Accepted 3 May 2013

Academic Editor: Anish Malladi

Copyright @ 2013 E. Bonora et al. This is an open access article distributed under the Creative Commons Attribution License, which permits unrestricted use, distribution, and reproduction in any medium, provided the original work is properly cited.

Consistency of fruit quality is extremely important in horticulture. Fruit growth and quality in nectarine are affected by fruit position in the canopy, related to the tree shape. The "open shaped" training systems, such as Tatura Trellis, improve fruit growth and quality. The Index of Absorbance Difference $\left(I_{\mathrm{AD}}\right)$ is a new marker that characterizes climacteric fruit during ripening. A study on fruit ripening was performed by using the $I_{\mathrm{AD}}$ on nectarine to monitor fruit maturity stages of two cultivars trained as Tatura Trellis in Victoria, Australia. Fruit of cv "Summer Flare 34" ("SF34") grown in different positions on the tree showed high ripening homogeneity. Fruit harvested at a similar ripening stage showed fruit firmness and soluble solid content homogeneity. Fruits from hand-thinned variety "Summer Flare 26" ("SF26") were larger in size, had advanced ripening, and showed greater homogeneity. For "SF26", a weak correlation between $I_{\mathrm{AD}}$ and SSC was observed. The experiment showed that the Tatura Trellis training system is characterized by high homogeneity of nectarine fruit when coupled with a proper management of fruit density. It also confirmed that the $I_{\mathrm{AD}}$ could be used as new nondestructive maturity index for nectarine fruit quality assessment in the field.

\section{Introduction}

A tree training system is defined as a method of manipulating the tree structure and canopy geometry to improve the interception and distribution of light, for the purpose of optimizing fruit quality and yield [1]. In 1970, a group of Australian researchers developed the Tatura Trellis [2], suitable for the complete mechanization of harvest in intensive peach orchards. Despite of the higher light available and photosynthetic rate that this tree shape allows, it was judged too expensive because of the intensive work needed to maintain the complex scaffold. Keeping the same open canopy design, simplified and cheaper tree shapes were developed during the following decades, such as the "KAC V" [3] and "Y" [1]. Several aspects of the Tatura Trellis training system on apple and cherry trees were studied [4], but only a few experiments on tree productivity were available regarding peach fruit [5]. Numerous studies on different tree architectures pointed out that fruit position in the canopy represents one of the most critical factors for peach fruit quality development and homogeneity of fruit characteristics [6-8] related to the light availability [9]. The open center training systems increase the light available in the inner canopy, giving rise to a gradient of quality traits. Fruit that develops in the periphery and center of the canopy obtains higher light levels and is characterized by better quality attributes, while fruits located halfway between the tree center and periphery are more shaded and developed lower quality $[8,9]$. Final fruit size and quality may also depend on shoot length, fruit distribution on the shoot, and number of fruit per centimeter of shoot length [10]. The correct management of the fruit density in relation to the position and light exposure is required to get optimal fruit size $[6,11]$. Several studies in the past attempted to evaluate crop load and fruit quality distribution in different training systems $[12,13]$. For tree shapes that allow a uniform light distribution, fruit thinning has to be consistently performed in every part of the tree [14]. Farina et al. [6] showed that a balanced peach fruit number on an open shape produced a greater number of large-sized fruit. 
As well as the final commercial diameter, the quality traits commonly used as indicators of peach and nectarine maturity stage into the orchard are the changes in fruit firmness and background color turning from green to yellow [15]. The changes observed in the appearance and quality traits are related to the time course of ethylene production in ripening, since peaches and nectarines are climacteric fruits. Peach fruit characteristics such as soluble solids content, red color, and background color show a clear gradient related to fruit position in the canopy $[6,7,9]$. Farina et al. [6] reported different gradients of peach fruit firmness in different training systems, while other authors found that light intensity did not affect fruit firmness [8]. Changes in the background color and fruit firmness in peaches are generally linked, but light interception or canopy position may alter the relationship between these two parameters [7]. In fact, while recent studies on peach fruit observed that as firmness declines, background color became more yellow and less green; it was also pointed out that fruit with similar background color harvested from different positions into the canopy may not have the same fruit firmness [7, 16]. Iglesias and Echeverría [17] reported that peach fruit firmness alone is not a satisfactory minimum maturity index because it varies between nectarine cultivars, and for a given cultivar firmness varies in relation to fruit size, climatic conditions, and agronomical practices. Instead, background color is an informative harvest index as it reflects the chlorophyll content of the fruit [18]. Cascales et al. [19] found that changes in peach fruit background color due to chlorophyll degradation are proportional to those perceived by a panel of assessors. Recently, based on the vis-NIR spectroscopy a new measurement, the "index of absorbance difference" $\left(I_{\mathrm{AD}}\right)$ that strongly correlates with the chlorophyll-a content and the ethylene production of peach and nectarine fruit was introduced [20]. The $I_{\mathrm{AD}}$ could be used for individual cultivars to define the ideal time to harvest in accordance with consumer preferences, as shown by its higher correlation with consumer acceptance than with the traditional quality parameters found by Gottardi et al. [21]. However, few results are available regarding the use of the $I_{\mathrm{AD}}$ as a ripening index for peach and nectarine fruit.

The objectives of this study were (a) to evaluate the possible application of the $I_{\mathrm{AD}}$ as a nondestructive maturity index to follow fruit ripening in the field and objectively define the ideal harvesting time, (b) to characterize the performance of the Tatura Trellis training system for nectarine in affecting fruit quality, maturity, and homogeneity.

\section{Materials and Methods}

Trials were conducted in 2010 on two six-year-old yellow flesh nectarines (Prunus persica [L.] Batsch) cultivar "Summer Flare 34" and "Summer Flare 26" grafted onto "GF677" (P. persica $\times$ P. dulcis). The orchards were located in Ardmona, Victoria, Australia ( $-36.38 \mathrm{~N}, 145.32 \mathrm{~S})$, and trees were trained to a North-South oriented Tatura Trellis system with spacing of $4.5 \mathrm{~m}$ between rows and $3.0 \mathrm{~m}$ within row $(4.5 \mathrm{~m} \times$ $3.0 \mathrm{~m}$ ) and a planting density of 740 trees/ha. Industry standard management techniques were applied throughout the
TABLE 1: Fruit maturity stage, $I_{\mathrm{AD}}$ value and corresponding ethylene production ( $\mathrm{nl} \mathrm{L}^{-1} \mathrm{~h}^{-1} \mathrm{~g}^{-1} \mathrm{FW}$ ) of the two nectarine varieties SF34 and SF26.

\begin{tabular}{lcccc}
\hline Variety & $\begin{array}{c}\text { Maturity } \\
\text { stage }\end{array}$ & $\begin{array}{c}I_{\mathrm{AD}} \\
\text { value }\end{array}$ & \multicolumn{2}{c}{$\begin{array}{c}\text { Ethylene emission } \\
\left(\mathrm{nl} \mathrm{L}^{-1} \mathrm{~h}^{-1} \mathrm{~g}^{-1} \mathrm{FW}\right)\end{array}$} \\
\hline \multirow{3}{*}{ SF34 } & $\mathrm{PM}^{\mathrm{z}}$ & $0.3-0.6$ & 2.13 & $\mathrm{a}^{\mathrm{y}}$ \\
& $\mathrm{CM}$ & $0.6-1.3$ & 0.26 & $\mathrm{~b}$ \\
& $\mathrm{I}$ & $1.3-1.6$ & 0.06 & $\mathrm{~b}$ \\
\hline \multirow{3}{*}{ SF26 } & PM & $0.3-0.6$ & 2.14 & $\mathrm{a}$ \\
& $\mathrm{CM}$ & $0.6-1.0$ & 0.40 & $\mathrm{~b}$ \\
& $\mathrm{I}$ & $1.0-1.3$ & 0.01 & $\mathrm{~b}$ \\
\hline
\end{tabular}

$\overline{{ }^{\mathrm{z}} \text { Fruit maturity stages: physiological maturity (PM), commercial maturity }}$ (CM), and immature (I).

${ }^{\mathrm{y}}$ Numbers with different letters would be statistically significant at $P<0.005$; $\mathrm{LSD}=0.05$

season in terms of pruning, irrigation, fertilization, and pest control. No summer pruning was applied, neither reflective mulches were used in the orchard under study. Full bloom dates recorded for the two cultivars were the 14th and 16th of October 2010 for "SF34" and "SF26", respectively. Three similar trees for "SF34" and six similar trees for "SF26" were randomly selected within each orchard. To understand intracanopy variability, the canopies were divided in three parallel horizontal areas of equal size representing the top $(\mathrm{T})$, middle (M), and bottom (B) canopy layers as described by He et al. [8].

Fruit maturity was assessed by measuring the Index of Absorbance Difference $\left(I_{\mathrm{AD}}\right)$ with the DA-Meter (TR, Forli, Italy), a portable vis/NIRs that correlates with chlorophyll-a content and ethylene production as described by Ziosi et al. [20]. Fruits of the two cultivars "SF34" and "SF26" were catalogued into three ripening classes at harvest representing physiological maturity (PM), that corresponded to the ethylene production; commercial maturity (CM); at the onset of climacteric and immature (I), the time before the climacteric (Table 1).

To detect the maturity stage at which the ethylene climacteric occurred in cultivars "SF34" and "SF26", ethylene production was assessed on a sample of 10 to 15 fruits per $I_{\mathrm{AD}}$ class (forty fruits in total), randomly picked one week before the main harvest. Fruits were individually placed in sealed $1 \mathrm{~L}$ jars, and a $1.0 \mathrm{~mL}$ gas sample removed and injected into a Shimadzu GC-14B packed-gas chromatograph (column = packed alumina SS $80 / 100180 \mathrm{~cm} ; 140^{\circ} \mathrm{C}$; Inj/Det $=180^{\circ} \mathrm{C}$, Shimadzu, Kyoto, Japan). Fruits were left to incubate for at least one hour at $20^{\circ} \mathrm{C}$ prior to a second gas sample being removed and injected into the GC. The ethylene production was calculated as the difference between the result of the second and the first injection.

For both cultivars at harvest, twenty to fifty fruits per $I_{\mathrm{AD}}$ class were assessed with the standard quality trait measured: fruit firmness (FF), soluble solids content (SSC), percent blush, and $\mathrm{a}^{*}$ and $\mathrm{b}^{*}$ on both blush and background color of the peel. Fruit firmness was measured on the two opposite cheeks using a FT011 hand-operated Effegi penetrometer (Effegi, Ravenna, Italy) equipped with an $8 \mathrm{~mm}$ diameter 


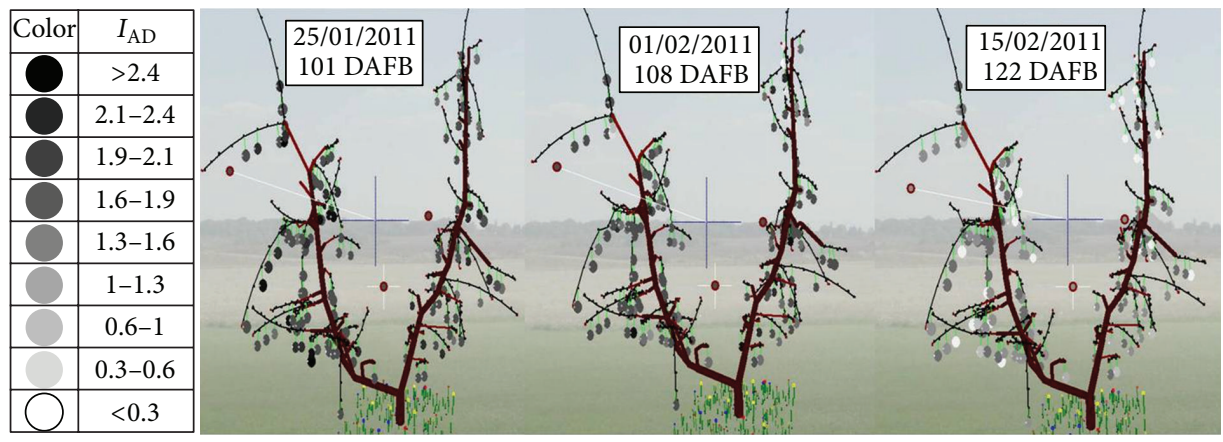

FIGURE 1: PlantToon image of the fruit ripening distribution $\left(I_{\mathrm{AD}}\right)$ at 101, 108, and $122 \mathrm{DAFB}\left(\mathrm{cv}\right.$ SF34). The white circles $\left(I_{\mathrm{AD}}<0.3\right)$ as well as the circles colored with the lighter shade of grey $\left(0.3<I_{\mathrm{AD}}<0.6\right)$ represent fruits at their physiological maturity stage $(\mathrm{PM})$. The higher the $I_{\mathrm{AD}}$ value and the more unripe the fruit, the darker the shade of grey. The most unripe fruits are represented by black circles $\left(I_{\mathrm{AD}}>1.4\right)$.

Magness-Taylor probe and mounted on a hand-operated drill press. Central portion of each fruit cheek was squeezed, and SSC was determined with a digital hand-held refractometer (PAL-1, Atago, Tokyo, Japan). The percent of blush was visually evaluated and expressed as percentage of the fruit surface covered with a uniform red color $(0 \%$ corresponded to a fruit that did not develop any blush; $100 \%$ corresponded to a fruit completely red). The $\mathrm{a}^{*}$ and $\mathrm{b}^{*}$ color-component dimensions, based on nonlinearly compressed coordinates, were measured with a CR400 Minolta digital colorimeter (Konica-Minolta, Tokyo, Japan).

"SF34" was used to evaluate the influence of the Tatura Trellis system on fruit maturity and quality. Five fruits per each canopy layer (bottom, middle, and top) from the east and west sides of the canopy of every tree were tagged (ninety fruits in total) and followed during the growing season. To evaluate the influence that fruit position within the canopy had on nectarine development, fruit growth (diameter) and ripening $\left(I_{\mathrm{AD}}\right)$ were weekly monitored on tagged fruits from 83 to 130 days after full bloom (DAFB). The first harvest was performed at $122 \mathrm{DAFB}$ and the main harvest at $130 \mathrm{DAFB}$. Fruit ripening distribution was measured with the DAmeter on a total population of 100 randomly selected fruits picked from the trees under study at the main harvest. The previously described standard laboratory quality assessments were performed on a sample of twenty to fifty fruits per $I_{\mathrm{AD}}$ class.

On one of the trees in trial, the spatial position of each fruit, as well as the complete canopy structure, was identified using a "woody stick-compass system" (Costa et al. [22]; personal communication) to obtain length, direction $\left({ }^{\circ} \mathrm{N}\right)$, and horizontal projection of each element following. By inputting the collected data in the $3 \mathrm{D}$ graphic software PlantToon [23], the architecture of the tree was recreated and modeled in order to link the relative position of each fruit with the information collected from the field $\left(I_{\mathrm{AD}}\right)$.

"SF26" was used to evaluate the effect of fruit density on fruit maturity of Tatura Trellis grown trees. Six branches with similar length (around 40 to $50 \mathrm{~cm}$ ), one branch per each canopy layer (bottom, middle, and top), and orientation (East, West) were selected and tagged on each of the six trees in trial (thirty-six branches in total), based on the assumption that peach tree branches behaved as functionally autonomous units, as demonstrated by Volpe et al. [24]. All tagged branches from three trees were hand thinned to 4 fruits per branch (1 fruit every $10-12 \mathrm{~cm}$ of shoot length) 15 to 20 DAFB (as suggested [10]), while all the tagged branches from the remaining three trees were left unthinned with roughly 8 fruits per branch (1 fruit every 5-6 cm of shoot length).

Fruit growth (diameter) and ripening $\left(I_{\mathrm{AD}}\right)$ were monitored weekly from 68 to 89 DAFB on the fruit from all tagged branches. As previously described, to assess the correlation between the fruit ripening stage $\left(I_{\mathrm{AD}}\right)$ and SSC, during fruit growth a sample of fifteen fruits was collected weekly. Harvest was performed in two picks one week apart (main harvest was at $89 \mathrm{DAFB}$ ). Because of an overwhelming infection of Monilia laxa near harvest, the standard laboratory quality assessments (FF and SSC) at harvest of "SF26" were not performed.

The study was organized as completely randomized design. All the collected data were statistically evaluated using the Duncan's multiple range $t$-test at $P<0.05$. The interactions between factors were assessed with a multiple factor ANOVA test. Both the statistical evaluations were performed with the software STATISTICA 7 (StatSoft. Inc., Tulsa, OK, USA).

\section{Results}

Table 1 shows the $I_{\mathrm{AD}}$ values at which the fruit maturity stage ranges start affecting the physiology of the fruit for both "SF34" and "SF26" nectarines. $I_{\mathrm{AD}}$ values were different for the two cultivars even when inside the same maturity stage. Fruits at an immature stage ( $>1.3 I_{\mathrm{AD}}$ value for "SF34" and $>1.0$ for "SF26") were preclimacteric with negligible ethylene production. Fruits at commercial maturity show the onset of the climacteric with the starting of ethylene production $\left(I_{\mathrm{AD}}\right.$ values of 0.6 to 1.3 for SF34 and 0.6 to 1.0 for SF26). Below a $0.6 I_{\mathrm{AD}}$ value in both cultivars, fruits were at the physiological maturity stage with high ethylene production.

As shown in Figure 1, at 101 and 108 DAFB fruits of the "SF34" were immature, with $I_{\mathrm{AD}}$ values greater than 1.3-1.6. At $122 \mathrm{DAFB}$, fruits in the outer canopy appeared riper than 


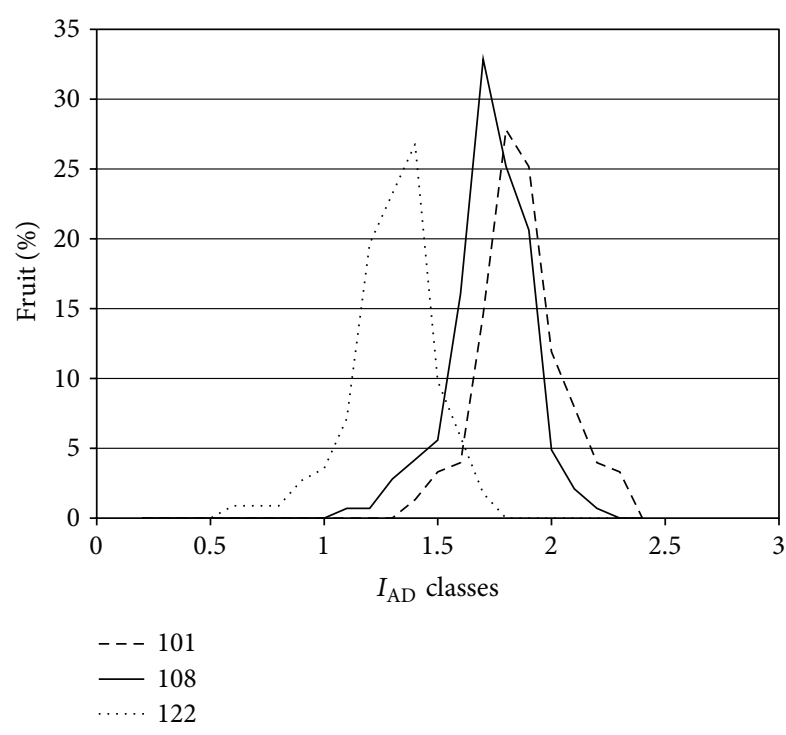

FIGURE 2: Fruit ripening distribution curves between $I_{\mathrm{AD}}$ classes at 101, 108, and 122 DAFB (SF34).

fruits in the inner and bottom canopies as shown by the light gray and white circles representing the riper fruit.

At every sampling, fruit ripening distribution between $I_{\mathrm{AD}}$ classes was concentrated in a narrow range of values (Figure 2), showing a high fruit ripening homogeneity. The three curves seemed to maintain the same shape over time and only sliding toward lower $I_{\mathrm{AD}}$ values when the fruit became riper (122 DAFB).

As shown in Table 2, significant differences were observed monitoring fruit ripening of the "SF34" every week from 93 to $130 \mathrm{DAFB}$ during which the $I_{\mathrm{AD}}$ values progressively decreased from around 1.8 to roughly 0.8 in a month.

Fruit reached the onset of climacteric at $122 \mathrm{DAFB}$ and harvested at 122 and 130 DAFB for "SF34" cultivar. The maturity stage of the fruit was not different between the three horizontal canopy layers, bottom, middle, and top, over time (data not shown), while fruit growth during the season was significantly affected by fruit positioning in the canopy (Table 3). At the first sampling (73 DAFB), fruits from the T canopy layer were larger in diameter than fruits in the $\mathrm{M}$ and B canopy layers $(44.5 \mathrm{~mm}, 42.8 \mathrm{~mm}$, and $41.2 \mathrm{~mm}$, resp.). For the rest of the season and up to the first harvest (122 DAFB), fruits in the B canopy layer had on average 2 to $4 \mathrm{~mm}$ smaller diameters than the $\mathrm{M}$ and $\mathrm{T}$ canopy layers (Table 3 ). At the main harvest (130 DAFB) of "SF34", no additional differences were observed between fruit diameters from the three canopy layers (average of 71 to $73 \mathrm{~mm}$ ).

Fruits of "SF34" showed a high ripening homogeneity at the main harvest (130 DAFB) at which more than $80 \%$ of the fruits were included in the CM class, whereas only $3 \%$ of the fruits were in the I class $\left(I_{\mathrm{AD}}\right.$ value greater than 1.3), and the remaining $(17 \%)$ were at the physiological maturity stage $\left(I_{\mathrm{AD}}\right.$ $0.3-0.6)$.

Riper fruit (PM) did not show any significant differences between bottom, middle, and top canopy layers in term of percent of blush at harvest (55 to 60\%). Fruits from top
TABLE 2: Average of the fruit maturity stage $\left(I_{\mathrm{AD}}\right)$ on the tree at 93, $101,108,122$, and 130 DAFB (cv SF34).

\begin{tabular}{lll}
\hline DAFB & & $I_{\mathrm{AD}}$ \\
\hline 93 & 1.87 & $\mathrm{a}^{\mathrm{z}}$ \\
101 & 1.81 & $\mathrm{~b}$ \\
108 & 1.65 & $\mathrm{c}$ \\
122 & 1.26 & $\mathrm{~d}$ \\
130 & 0.78 & $\mathrm{e}$ \\
\hline
\end{tabular}

${ }^{\mathrm{z}}$ Numbers with different letters would be statistically significant at $P<$ $0.005 ; \mathrm{LSD}=0.05$.

TABLE 3: Average of the fruit diameter in the bottom (B), middle (M), and top (T) canopy layers of the tree at 73, 80, 93, 101, 108, 122, and 130 DAFB (cv SF34).

\begin{tabular}{|c|c|c|c|}
\hline \multirow[t]{2}{*}{ DAFB } & \multirow{2}{*}{$\begin{array}{c}\text { Layer } \\
\text { B }\end{array}$} & \multicolumn{2}{|c|}{ Diameter (mm) } \\
\hline & & 41.2 & $\mathrm{~b}^{\mathrm{z}}$ \\
\hline \multirow[t]{3}{*}{73} & $\mathrm{M}$ & 42.8 & $\mathrm{~b}$ \\
\hline & $\mathrm{T}$ & 44.5 & $\mathrm{a}$ \\
\hline & $\mathrm{B}$ & 42.7 & $\mathrm{~b}$ \\
\hline \multirow[t]{3}{*}{80} & M & 44.6 & a \\
\hline & $\mathrm{T}$ & 46.0 & $\mathrm{a}$ \\
\hline & B & 50.4 & $\mathrm{~b}$ \\
\hline \multirow[t]{3}{*}{93} & M & 53.3 & a \\
\hline & $\mathrm{T}$ & 55.3 & $\mathrm{a}$ \\
\hline & B & 54.5 & $\mathrm{~b}$ \\
\hline \multirow[t]{3}{*}{101} & M & 57.1 & $\mathrm{ab}$ \\
\hline & $\mathrm{T}$ & 57.7 & $\mathrm{a}$ \\
\hline & B & 58.7 & $\mathrm{~b}$ \\
\hline \multirow[t]{3}{*}{108} & M & 61.2 & a \\
\hline & $\mathrm{T}$ & 62.3 & $\mathrm{a}$ \\
\hline & B & 65.9 & $\mathrm{~b}$ \\
\hline \multirow[t]{3}{*}{122} & M & 69.4 & a \\
\hline & $\mathrm{T}$ & 69.2 & $\mathrm{a}$ \\
\hline & B & 71.1 & $\mathrm{a}$ \\
\hline \multirow[t]{2}{*}{130} & M & 71.3 & a \\
\hline & $\mathrm{T}$ & 73.2 & a \\
\hline
\end{tabular}

${ }^{\mathrm{z}}$ Numbers with different letters would be statistically significant at $P<$ 0.005 .

canopy layer of the CM class were more colored (60\% blush) than bottom fruit ( $40 \%$ blush) of the same class, while no differences were shown between fruits of the I class, that developed only $10 \%$ blush, independent of the canopy layer. Immature fruits that were east exposed had less blush than west-oriented fruits (data not shown). No significant differences between ripening classes and canopy layers in term of $\mathrm{a}^{*}$ and $\mathrm{b}^{*}$ components of both blush and background color were observed (data not shown), while traditional destructive quality parameters were differently affected by the fruit ripening stage and the position in the canopy, as shown in Table 4.

No differences were observed for fruit firmness between fruits within the same ripening class, coming from the three canopy layers. If we consider the canopy layers, only the 
TABLE 4: Average of firmness ( $\mathrm{FF} \mathrm{kg} / \mathrm{cm}^{2}$ ) and soluble solids content ( $\mathrm{SSC}{ }^{\circ} \mathrm{Brix}$ ) of fruits at the $I_{\mathrm{AD}}$ classes of physiological maturity (PM), commercial maturity (CM), and immature (I) in the three canopy layers; bottom (B), middle (M), and top (T) of "SF34".

\begin{tabular}{|c|c|c|c|c|c|c|c|c|c|c|c|c|c|c|c|c|c|c|}
\hline \multirow{3}{*}{$\begin{array}{l}\begin{array}{l}I_{\mathrm{AD}} \\
\text { class }\end{array} \\
\mathrm{PM}\end{array}$} & \multicolumn{9}{|c|}{$\mathrm{FF}\left(\mathrm{kg} / \mathrm{cm}^{2}\right)$} & \multicolumn{9}{|c|}{ SSC $\left({ }^{\circ}\right.$ Brix $)$} \\
\hline & \multicolumn{3}{|c|}{$\mathrm{B}$} & \multicolumn{3}{|c|}{ M } & \multicolumn{3}{|c|}{$\mathrm{T}$} & \multicolumn{3}{|c|}{ B } & \multicolumn{3}{|c|}{ M } & \multicolumn{3}{|c|}{$\mathrm{T}$} \\
\hline & 6.6 & $a^{z}$ & $\mathrm{~A}^{\mathrm{y}}$ & 6.5 & $\mathrm{a}$ & A & 5.9 & $\mathrm{a}$ & B & 12.0 & $\mathrm{~b}$ & A & 12.3 & $\mathrm{ab}$ & A & 13.4 & $\mathrm{a}$ & A \\
\hline $\mathrm{CM}$ & 6.7 & $\mathrm{a}$ & A & 6.9 & a & A & 6.8 & $\mathrm{a}$ & $\mathrm{AB}$ & 12.4 & $\mathrm{~b}$ & A & 12.6 & $\mathrm{~b}$ & $\mathrm{AB}$ & 13.6 & a & A \\
\hline I & 6.5 & $\mathrm{a}$ & A & 6.5 & a & A & 7.1 & a & $\mathrm{A}$ & 11.9 & a & A & 11.6 & a & $\mathrm{B}$ & 12.3 & $\mathrm{a}$ & B \\
\hline
\end{tabular}

${ }^{{ }^{z}}$ Small letters represent significant differences between canopy layers within the same $I_{\mathrm{AD}}$ class at $P<0.05$.

${ }^{\mathrm{y}}$ Capital letters represent significant differences between $I_{\mathrm{AD}}$ values within the same canopy layer at $P<0.05$.

TABLE 5: Average fruits diameters in the hand-thinned and unthinned fruit densities in the bottom (B), middle (M), and top (T) canopy layers at $68,75,82$, and 89 DAFB ("SF26").

\begin{tabular}{lccccccc}
\hline DAFB & Layer & \multicolumn{2}{c}{$\begin{array}{c}\text { Hand-Thinned } \\
\text { (diameter-mm) }\end{array}$} & \multicolumn{3}{c}{$\begin{array}{c}\text { Unthinned } \\
\text { (diameter-mm) }\end{array}$} \\
\hline \multirow{2}{*}{68} & $\mathrm{~B}$ & 46.9 & $\mathrm{a}^{\mathrm{z}}$ & $\mathrm{A}^{\mathrm{y}}$ & 35.8 & $\mathrm{~b}$ & $\mathrm{~B}$ \\
& $\mathrm{M}$ & 47.3 & $\mathrm{a}$ & $\mathrm{A}$ & 37.3 & $\mathrm{~b}$ & $\mathrm{~B}$ \\
& $\mathrm{~T}$ & 45.2 & $\mathrm{a}$ & $\mathrm{A}$ & 40.5 & $\mathrm{~b}$ & $\mathrm{~A}$ \\
\hline \multirow{3}{*}{75} & $\mathrm{~B}$ & 53.3 & $\mathrm{a}$ & $\mathrm{A}$ & 40.4 & $\mathrm{~b}$ & $\mathrm{~B}$ \\
& $\mathrm{M}$ & 54.2 & $\mathrm{a}$ & $\mathrm{A}$ & 41.4 & $\mathrm{~b}$ & $\mathrm{~B}$ \\
& $\mathrm{~T}$ & 51.7 & $\mathrm{a}$ & $\mathrm{A}$ & 46.0 & $\mathrm{~b}$ & $\mathrm{~A}$ \\
\hline & $\mathrm{B}$ & 59.1 & $\mathrm{a}$ & $\mathrm{A}$ & 43.1 & $\mathrm{~b}$ & $\mathrm{~B}$ \\
& $\mathrm{M}$ & 57.3 & $\mathrm{a}$ & $\mathrm{A}$ & 45.6 & $\mathrm{~b}$ & $\mathrm{AB}$ \\
& $\mathrm{T}$ & 56.3 & $\mathrm{a}$ & $\mathrm{A}$ & 49.4 & $\mathrm{~b}$ & $\mathrm{~A}$ \\
\hline & $\mathrm{B}$ & 62.9 & $\mathrm{a}$ & $\mathrm{A}$ & 45.9 & $\mathrm{~b}$ & $\mathrm{~A}$ \\
& $\mathrm{M}$ & 61.9 & $\mathrm{a}$ & $\mathrm{A}$ & 46.3 & $\mathrm{~b}$ & $\mathrm{~A}$ \\
& $\mathrm{~T}$ & 56.8 & $\mathrm{a}$ & $\mathrm{A}$ & 48.2 & $\mathrm{~b}$ & $\mathrm{~A}$ \\
\hline
\end{tabular}

${ }^{{ }^{z}}$ Small letters represent significant differences between fruit densities within the same canopy layer $(\mathrm{B}, \mathrm{M}$, and $\mathrm{T})$ at $P<0.05$.

${ }^{\mathrm{y}}$ Capital letters represent significant differences between canopy layers within the same fruit density (hand thinned or unthinned) at $P<0.05$.

top showed variation between ripening classes, with riper fruit (PM) measuring the lowest fruit firmness and immature fruit I the highest (Table 4). Fruits of both the PM and CM classes developed the highest SSC at the top of the trees, while no differences were noticed between tree canopy layers within the immature $I_{\mathrm{AD}}$ class. When comparing fruits within the same canopy layer, fruits at the $\mathrm{PM}$ and $\mathrm{CM}$ ripening stages showed higher SSC values than (I) fruits, while no differences were noticed between ripening classes in the bottom canopy layer (Table 4). Both fruits' firmness and SSC were not affected by fruit orientation (East West) in the canopy (data not shown).

As shown in Table 5 for "SF26", hand-thinned fruits were bigger than the unthinned at every sampling date and in all tree canopy layers. When considering fruit density (hand thinned and unthinned) inside each canopy layer, the diameter of the hand-thinned fruit did not differ between canopy layers at any sampling date. The unthinned fruits were bigger in the top than in the other canopy layers at most sampling dates. Only at $89 \mathrm{DAFB}$, all fruits from the three
TABLE 6: Average of fruit ripening stage $\left(I_{\mathrm{AD}}\right)$ in the hand-thinned and unthinned treatments, in the three canopy layers (B, $\mathrm{M}$, and $\mathrm{T})$, at $68,75,82$, and 89 DAFB ("SF26").

\begin{tabular}{lccccccc}
\hline DAFB & Layer & \multicolumn{3}{c}{$\begin{array}{c}\text { Hand-Thinned } \\
\text { (ripening- } I_{\mathrm{AD}} \text { ) }\end{array}$} & \multicolumn{3}{c}{$\begin{array}{c}\text { Unthinned } \\
\text { (ripening- } I_{\mathrm{AD}} \text { ) }\end{array}$} \\
\hline \multirow{6}{*}{68} & $\mathrm{~B}$ & 1.84 & $\mathrm{~b}^{\mathrm{z}}$ & $\mathrm{A}^{\mathrm{y}}$ & 1.99 & $\mathrm{a}$ & $\mathrm{A}$ \\
& $\mathrm{M}$ & 1.82 & $\mathrm{~b}$ & $\mathrm{~A}$ & 1.96 & $\mathrm{a}$ & $\mathrm{A}$ \\
& $\mathrm{T}$ & 1.89 & $\mathrm{a}$ & $\mathrm{A}$ & 1.91 & $\mathrm{a}$ & $\mathrm{A}$ \\
\hline \multirow{6}{*}{75} & $\mathrm{~B}$ & 1.64 & $\mathrm{~b}$ & $\mathrm{~A}$ & 1.76 & $\mathrm{a}$ & $\mathrm{A}$ \\
& $\mathrm{M}$ & 1.64 & $\mathrm{~b}$ & $\mathrm{~A}$ & 1.71 & $\mathrm{a}$ & $\mathrm{A}$ \\
& $\mathrm{T}$ & 1.66 & $\mathrm{a}$ & $\mathrm{A}$ & 1.69 & $\mathrm{a}$ & $\mathrm{A}$ \\
\hline \multirow{3}{*}{82} & $\mathrm{~B}$ & 1.33 & $\mathrm{~b}$ & $\mathrm{~A}$ & 1.58 & $\mathrm{a}$ & $\mathrm{A}$ \\
& $\mathrm{M}$ & 1.28 & $\mathrm{~b}$ & $\mathrm{~A}$ & 1.48 & $\mathrm{a}$ & $\mathrm{A}$ \\
& $\mathrm{T}$ & 1.18 & $\mathrm{~b}$ & $\mathrm{~A}$ & 1.45 & $\mathrm{a}$ & $\mathrm{A}$ \\
\hline \multirow{3}{*}{89} & $\mathrm{~B}$ & 0.92 & $\mathrm{~b}$ & $\mathrm{~A}$ & 1.29 & $\mathrm{a}$ & $\mathrm{A}$ \\
& $\mathrm{M}$ & 0.72 & $\mathrm{~b}$ & $\mathrm{~A}$ & 1.28 & $\mathrm{a}$ & $\mathrm{A}$ \\
& $\mathrm{T}$ & 0.88 & $\mathrm{~b}$ & $\mathrm{~A}$ & 1.21 & $\mathrm{a}$ & $\mathrm{A}$ \\
\hline
\end{tabular}

${ }^{\mathrm{z}}$ Small letters represent significant differences between fruit densities within the same canopy layer (B, M, and $\mathrm{T}$ ) at $P<0.05$.

${ }^{\mathrm{y}}$ Capital letters represent significant differences between canopy layers within the same fruit density (hand thinned or unthinned) at $P<0.05$.

canopy layers reached the same diameter in the unthinned trees, and no statistical differences were observed.

Table 6 shows the $I_{\mathrm{AD}}$ values decreased during the season for both the hand-thinned and thinned treatments. Within fruit densities for every sampling time, no differences were observed between the three canopy layers. Fruit density had an interactive effect with canopy layer on fruit $I_{\mathrm{AD}}$ values. Higher fruit densities at 68 and 75 DAFB resulted in delayed ripening values in fruit from the middle and bottom canopy layers but not from the top canopy layer. In all subsequent sampling dates, unthinned fruits showed delayed maturity (lower $I_{\mathrm{AD}}$ values) when compared with the hand-thinned fruits reaching the point at $89 \mathrm{DAFB}$ (harvest) in which unthinned fruits were still at a preclimacteric stage while hand-thinned fruits were already at the onset of climacteric (Tables 1 and 6). The east or west orientation did not affect the fruit growth or ripening (data not shown).

Figure 3 describes the correlation, with a coefficient of determination of $R^{2}=0.60(P<0.01)$, between the $I_{\mathrm{AD}}$ values of fruit of "SF26" and the respective SSC during fruit 


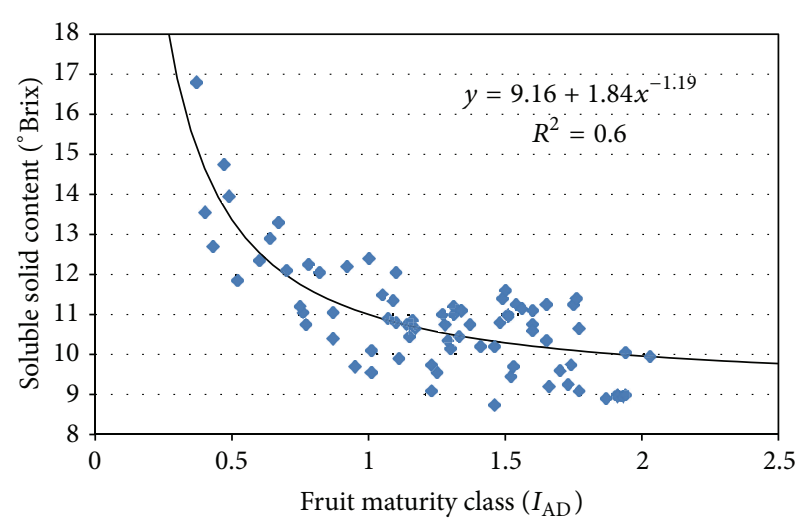

FIGURE 3: Correlation between fruit ripening stage $\left(I_{\mathrm{AD}}\right)$ and soluble solids content ( ${ }^{\circ}$ Brix) "SF26".

growth. Unripe fruit with an $I_{\mathrm{AD}}$ between 1.0 and 2.0 had a lower SSC than the riper fruit. Fruits that reached the PM showed the highest SSC $\left(12-15^{\circ}\right.$ Brix $)$.

\section{Discussion}

Recently, Reig et al. [25] used firmness instead of ethylene production to establish a correlation between the $I_{\mathrm{AD}}$ and fruit maturity stage, but their findings were not satisfactory as different $I_{\mathrm{AD}}$ values were obtained at different firmness values, and the relationship was cultivar dependent. In fact, as demonstrated by Ziosi et al. [20] on "Stark Red Gold" nectarine, $I_{\mathrm{AD}}$ had a higher correlation with ethylene production than with fruit firmness. Both "SF34" and "SF26" showed a clear and different trend in ethylene production at the respective I, CM, and PM fruit maturity stages (Table 1), which agreed with Ziosi et al. [20] who defined the relationship between ethylene production and ripening stage $\left(I_{\mathrm{AD}}\right)$ as cultivar specific. The $I_{\mathrm{AD}}$ can be regarded as a marker for peach fruit ripening that is more sensitive and confident than the physicochemical parameters commonly used to describe physiological condition including firmness, which was the most reliable measurement until now [26].

The $I_{\mathrm{AD}}$ value measured on fruit of "SF34" decreased following ripening from four-six weeks after full bloom (Table 2), even if at the onset of climacteric (CM) the ethylene production still remained very low (Table 1). Prior to the CM ripening stage, at the immature stage, the $I_{\mathrm{AD}}$ probably better correlates with chlorophyll content than with the ethylene production, though still remaining cultivar specific [27, 28]. Ripening assessment on fruit of "Stark Red Gold" [20] as well as on eleven different nectarine cultivars by Reig et al. [25] confirmed the same behavior.

The nondestructive DA-meter, coupled with the 3D representation of the tree, permitted objective observations of fruit ripening in their exact location within the canopy (Figure 1), without removing them from the tree (Costa et al. [29], personal communication). Our experiment showed that fruit ripening $\left(I_{\mathrm{AD}}\right)$ of "SF34" trained on a Tatura Trellis was not affected by fruit position inside the canopy (bottom, middle, and top canopy layers) during the season as well as at harvest (Figures 1 and 2). This is probably due to the open shape of the training system that allows better exposure of fruits in the inner and bottom parts of the canopy to direct sunlight, especially during the latter stages of fruit development [30]. A similar behavior was observed on peach and apple fruits grown on a Y-trellis [1], characterized by a wider angle between branches $\left(27.5^{\circ}\right.$ instead of the $17.5^{\circ}$ from vertical for the Tatura Trellis) and "perpendicular V" also called "Kearney-V" or "KAC-V" [3], a hybrid between the traditional open-vase system and the Tatura Trellis. All these training systems showed greater levels of intercepted radiation than the delayed vase and free palmette for the life of the orchard [31].

Fruit ripening seemed not to be affected by fruit position, while growth and fruit final size for "SF34" (Table 3) appeared to be strongly affected by the fruit position in the canopy (Table 3). Several studies on peach trees have demonstrated that the fruit position in the canopy was an important factor affecting fruit growth and size [32, 33]. At every sampling, fruits of SF34 located at the top of the canopy were consistently bigger than the fruits in the bottom (Table 3). Also Lewallen and Marini [9] observed that the fruit size was the largest in fruits located in the outside of the canopy, and a similar pattern was reported in peach trees trained to a perpendicular-Y and "delayed vase" [6]. Basile et al. [34] showed that at harvest fruit size increased moving from the top to the bottom of the canopy, while at the beginning of the growing season fruits showed an opposite trend. Likewise, only at the first sampling (73 DAFB) on "SF34", no differences were observed between the diameters of fruits from the middle and bottom canopy layers, while afterwards the diameters of fruits from the middle and top canopy layers were similar until harvest (Table 3). This behaviour could be due to a change in fruit diameter gradient in the canopy described by Basile et al. [34]. A possible explanation of the opposite trend early in the season of fruit growth could be related to the time of blooming that starts from the tree bottom to the top of the tree [35]. Alternatively, part of the variability in fruit growth appeared to be related to carbon (C) source limitation due to the insufficient area of leaves per fruit early in the season $[10,14]$. In peach, which carries vegetative and reproductive buds at most nodes, the competition may be stronger for young fruit, and this may cause stronger early fruit-to-fruit competition in the top compared to the bottom of the canopy and a slow growth in the upper part of the trees [10]. Subsequently, when fruits become a stronger competitor for the photosynthates, they start to use the leaves in the vicinity as C-sources. Thus, fruits in the tree top are at an advantage because they are more exposed to light [34]. Fruit competition and use of leaves as Csources could explain our findings that after the main harvest (corresponding to fruits reaching the commercial maturity stage) of cV "SF34", fruit diameters were similar in the three considered canopy layers, probably because fruit removal caused a redistribution of the photosynthates between the remaining fruits, which continued their growth throughout the last stages of maturation [36]. An additional explanation could be that the removal of larger fruits, often harvested in the first pick and mainly located in the top or outside 
of the canopy, allows the remaining fruits to reach similar diameters.

Our results showed that fruit of "SF34", trained on Tatura Trellis, with the same ripening stage at harvest, were very homogeneous also in terms of firmness (Table 4) establishing a loose correlation between fruit firmness and ethylene production. This observation is in accord with other authors, who reported a rapid decline of fruit firmness after ethylene production inside the fruit has begun [37, 38]. Conversely, Lewallen and Marini [9] observed that fruit with similar background color, as an indication of fruit ripening, harvested from different positions within the canopy did not have the same fruit firmness, with firmer fruit in the inside positions of which the nearby leaves would be the least exposed to light. Our findings were somewhere in the middle since fruit from the bottom and middle canopy layer were found having similar firmness independently of their ripening stages (Table 4) while fruit from the top of the canopy showed that less ripened fruit were more firm, probably also due to a combined effect of light and position as suggested by Marini and Trout [39].

Ziosi et al. [20] described SSC as ethylene independent and did not observe strong differences in soluble solids between ripening stages $\left(I_{\mathrm{AD}}\right)$ for the "Stark Red Gold." Our results on "SF26" seemed to validate these findings. In fact, a relatively low correlation $\left(R^{2}=0.60\right)$ between $I_{\mathrm{AD}}$ and SSC was observed (Figure 3). These results were also in agreement with Hale et al. [40] for "August Fire" but in contrast to a recent publication by Infante et al. [18] on two cultivars of Japanese plums, "Angeleno" and "Autumn Beauty". Infante [41] described the $I_{\mathrm{AD}}$ as an index having high correlation with the most common parameters used for monitoring ripening, such as fruit firmness and SSC with $R^{2}>0.89$ and $>0.70$, respectively. Our results for "SF34" (Table 4), however, showed that only fruit from the bottom canopy layer appeared to have the same SSC, independent from the ripening stage. Overall in our experiments, it seems that there was a low interaction between canopy position and fruit ripening stage in regards to SSC (Table 4), and most of the effects were probably due to the higher exposure to light for fruit in the upper parts of the canopy than to their specific ripening stages, since only the immature or less exposed fruit of the bottom canopy layers had lower SSC. This hypothesis is supported by other research that found a strong influence of light on peach fruit quality [1] and, consequently, of tree growth trends, reproductive habits, training systems, and pruning techniques for light distribution [42, 43]. Despite the variation in SSC fruit content found in our experiment, trees trained in the Tatura Trellis system seemed to have a good uniformity in SSC distribution since $97 \%$ of the fruit at harvest were at the CM and PM maturity stage. Only 30\% came from the bottom canopy layer, with over $80 \%$ of the total fruit harvested having similar soluble solids content. There could also be a variety component influencing the overall correlation between SSC and $I_{\mathrm{AD}}$ and more research is necessary to validate this.

The highly uniform tree structure created by the Tatura Trellis system seemed to be the reason for the relatively high fruit uniformity found in our experiment, in terms of fruit maturity level, SSC, and firmness. In fact, as suggested by DeJong et al. [44], the uniform tree structure of Tatura Trellis also allows for an easy regulation of fruit density which can be summed by just leaving about four fruit per fruiting shoot during stage I of fruit growth [10]. From our experiment on "SF26", it was observed that maintaining fruit numbers at the suggested density resulted in uniform fruit within the canopy, both in terms of diameter and ripening stage (Tables 5 and 6). These results are in contrast with previous studies that showed gradients of fruit sizes within peach tree canopies both in commercially and heavily-thinned peach trees $[6,33,45]$. The higher light availability to the fruit, coupled with a balanced crop load, probably allowed the Tatura Trellis to reduce the fruit-to-fruit competition with a greater distribution of the photosynthates between vegetative and reproductive structures [46-48], which would explain the high fruit variability in terms of size and maturity stage that we found when fruit density was doubled (Tables 5 and 6). Our results were confirmed by other authors that observed that leaving too many fruit on a tree reduces SSC as well as fruit sizes at harvest $[10,49]$.

\section{Conclusions}

The present study showed that nectarine trees trained to Tatura Trellis produced fruit with high homogeneity in terms of growth, maturation, and SSC content, when fruit density is balanced. Our results also confirmed that the $I_{\mathrm{AD}}$ can be regarded as a sensitive, confident, and nondestructive marker of nectarine fruit maturity stage that allows for an early assessment of fruit ripening still on the tree. Further investigations are required to better define the relationship between $I_{\mathrm{AD}}$ and the traditional quality traits, fruit firmness and SSC.

\section{Acknowledgments}

This paper is a publication from a University of Bologna, College of Agriculture, Italy $\mathrm{PhD}$ dissertation thesis performed in Australia during the required international study period abroad. The authors thank the DPI Knoxfield Centre, for hosting and cofunding the experiment under Premium Fruit, a Victorian Department of Primary Industries project. Also thanks go to Rick Varapodio for making his orchards available, John Lopresti for helping in the field measurements, and the rest of the staff of the DPI Knoxfield Centre postharvest group for help and support in the laboratory.

\section{References}

[1] T. Caruso, C. Di Vaio, F. Guarino, A. Motisi, and V. Nuzzo, "Peach varieties for intensive plantations in Southern Italy," in 4th Congresso Nazionale Sulla Peschicoltura Meridionale, F. P. Marra and F. Sottile, Eds., pp. 44-51, Panuzzo Prontostampa, Caltanisseta, Italy, 2003.

[2] D. J. Chalmers and I. B. Wilson, "Productivity of peach trees: tree growth and water stress in relation to fruit growth and 
assimilate demand," Annals of Botany, vol. 42, no. 2, pp. 285294, 1978.

[3] T. M. DeJong, "Developmental and environmental control of dry-matter partitioning in peach," HortScience, vol. 34 , no. 6 , pp. 1037-1040, 1999.

[4] E. D. Cittadini, N. de Ridder, P. L. Peri, and H. van Keulen, "Relationship between fruit weight and the fruit-to-leaf area ratio, at the spur and whole-tree level, for three sweet cherry varieties," Acta Horticulturae, vol. 795, pp. 669-672, 2008.

[5] B. van den Ende, “The tatura trellis," Compact Fruit Tree, vol. 27, article 97, 1994.

[6] V. Farina, R. Lo Bianco, and P. Inglese, "Vertical distribution of crop load and fruit quality within vase- and Y-shaped canopies of "Elegant Lady" peach," HortScience, vol. 40, no. 3, pp. 587-591, 2005.

[7] M. Dani, "Connection between the light availability and the peach fruit quality," Cereal Research Communications, vol. 35, no. 2, pp. 337-340, 2007.

[8] F. L. He, F. Wang, Q. P. Wei, X. W. Wang, and Q. Zhang, "Relationships between the distribution of relative canopy light intensity and the peach yield and quality," Agricultural Sciences in China, vol. 7, no. 3, pp. 297-302, 2008.

[9] K. S. Lewallen and R. P. Marini, "Relationship between flesh firmness and ground color in peach as influenced by light and canopy position," Journal of the American Society for Horticultural Science, vol. 128, no. 2, pp. 163-170, 2003.

[10] L. Corelli Grappadelli and D. C. Coston, "Thinning pattern and light environment in peach tree canopies influence fruit quality," HortScience, vol. 26, no. 12, pp. 1464-1466, 1991.

[11] T. Caruso, A. de Michele, F. Sottile, and F. P. Marra, "La peschicoltura siciliana nel contesto italiano: ambiente, cultivar e tecniche colturali," in 2nd Atti Convegno sulla Peschicoltura Meridionale, pp. 83-88, Paestum, Italy, July 1998.

[12] S. Sansavini, L. Corelli, and L. Giunchi, "Peach yield efficiency as related to tree shape," Acta Horticulturae, vol. 173, pp. 139-158, 1985.

[13] L. C. Grappadelli and S. Sansavini, "Light interception and photosynthesis related to planting density and canopy management in apple," Acta Horticulturae, vol. 243, pp. 159-174, 1989.

[14] G. Costa, M. Noferini, G. Fiori, and A. Orlandi, "Nondestructive technique to assess internal fruit quality," Acta Horticulturae, vol. 603, pp. 571-575, 2003.

[15] M. Delwiche and R. A. Baumgardner, "Ground color measurements of peach," Journal of the American Society for Horticultural Science, vol. 108, pp. 1012-1016, 1983.

[16] R. P. Marini, D. Sowers, and M. C. Marini, "Peach fruit quality is affected by shade during final swell of fruit growth," Journal of the American Society for Horticultural Science, vol. 116, no. 3, pp. 383-389, 1991.

[17] I. Iglesias and G. Echeverría, "Differential effect of cultivar and harvest date on nectarine colour, quality and consumer acceptance," Scientia Horticulturae, vol. 120, no. 1, pp. 41-50, 2009.

[18] R. Infante, C. Pía, M. Noferini, and G. Costa, "Determination of harvest maturity of D'Agen plums using the chlorophyll absorbance index," Ciencia e Investigación Agraria, vol. 38, no. 2, pp. 199-203, 2011.

[19] A. I. Cascales, E. Costell, and F. Romojaro, "Effects of the degree of maturity on the chemical composition, physical characteristics and sensory attributes of peach (Prunus persicas) cv. caterin," Food Science and Technology International, vol. 11, no. 5, pp. 345-352, 2005.
[20] V. Ziosi, M. Noferini, G. Fiori et al., "A new index based on vis spectroscopy to characterize the progression of ripening in peach fruit," Postharvest Biology and Technology, vol. 49, no. 3, pp. 319-329, 2008.

[21] F. Gottardi, M. Noferini, G. Fiori, M. Barbanera, C. Mazzini, and G. Costa, "The index of absorbance difference $\left(\mathrm{I}_{\mathrm{AD}}\right)$ as a tool for segregating peaches and nectarines into homogeneous classes with different shelf-life and consumer acceptance," in Proceedings of the 8th Pangborn Sensory Science Symposium, Firenze, Italy, 2009.

[22] Costa et al., Proceedings of the 7th International Symposium on Kiwifruit, University of Bologna, 2010.

[23] E. Magnanini, E. Bonora, and G. Vitali, "PlantToon-drawing and pruning fruit trees," in Proceedings of the 6th International Workshop on Functional-Structural Plant Models, p. 255, Davis, Calif, USA, September 2010.

[24] G. Volpe, R. Lo Bianco, and M. Rieger, "Carbon autonomy of peach shoots determined by 13C-photoassimilate transport," Tree Physiology, vol. 28, no. 12, pp. 1805-1812, 2008.

[25] G. Reig, S. Alegre, I. Iglesias, G. Echeverría, and F. Gatius, "Fruit quality, colour development and index of absorbance difference $\left(I_{\mathrm{AD}}\right)$ of different nectarine cultivars at different harvest dates," in Proceedings of the 28th IHC International Symposium on Postharvest Technology, vol. 934, pp. 1117-1126, Acta Horticulturae, 2012.

[26] C. Valero, C. H. Crisosto, and D. Slaughter, "Relationship between nondestructive firmness measurements and commercially important ripening fruit stages for peaches, nectarines and plums," Postharvest Biology and Technology, vol. 44, no. 3, pp. 248-253, 2007.

[27] R. Cubeddu, C. D’Andrea, A. Pifferi et al., "Nondestructive quantification of chemical and physical properties of fruits by time-resolved reflectance spectroscopy in the wavelength range 650-1000 nm," Applied Optics, vol. 40, no. 4, pp. 538-543, 2001.

[28] R. Cubeddu, C. D’Andrea, A. Pifferi et al., "Time-resolved reflectance spectroscopy applied to the nondestructive monitoring of the internal optical properties in apples," Applied Spectroscopy, vol. 55, no. 10, pp. 1368-1374, 2001.

[29] Costa et al., Proceedings of the 10 International Symposium on Integrating Canopy, Rootstock and Environmental Physiology in Orchard Systems, University of Bologna, 2012.

[30] V. Nuzzo, B. Dichio, A. M. Palese, and C. Xiloyannis, "Sviluppo della chioma ed intercettazione radiativa in piante di pesco allevate ad $\mathrm{Y}$ trasversale ed a vaso ritardato nei primi tre anni dall'impianto," in Proceedings of 5th Giornate Scientifiche SOI, O. Failla and I. Piagnani, Eds., pp. 319-320, Edizioni Tecnos, Milan, Italy, 2000.

[31] L. C. Grappadelli and R. P. Marini, "Orchard planting systems," in The Peach: Botany, Production and Uses, D. R. Layne and D. Bassi, Eds., pp. 264-288, 2008.

[32] M. Génard and C. Bruchou, "A functional and exploratory approach to studying growth: the example of the peach fruit," Journal of the American Society for Horticultural Science, vol. 118, pp. 317-323, 1993.

[33] A. Weibel, Effect of size-controlling rootstocks on vegetative and reproductive growth of peach [Prunus persica (L.) Batsch] [M.S. thesis], University of California, Davis, Calif, USA, 1999.

[34] B. Basile, L. I. Solari, and T. M. Dejong, "Intra-canopy variability of fruit growth rate in peach trees grafted on rootstocks with different vigour-control capacity," Journal of Horticultural Science and Biotechnology, vol. 82, no. 2, pp. 243-256, 2007. 
[35] I. R. Dann and P. H. Jerie, "Gradients in maturity and sugar levels of fruit within peach trees," Journal of the American Society for Horticultural Science, vol. 113, pp. 27-31, 1988.

[36] R. P. Marini and D. L. Sowers, "Peach fruit weight is influenced by crop density and fruiting shoot length but not position on the shoot," Journal of the American Society for Horticultural Science, vol. 119, no. 2, pp. 180-184, 1994.

[37] P. Tonutti, C. Bonghi, and A. Ramina, "Fruit firmness and ethylene biosynthesis in three cultivars of peach (Prunus persica L. Batsch)," Journal of Horticultural Science and Biotechnology, vol. 71, no. 1, pp. 141-147, 1996.

[38] D. A. Brummell, V. D. Cin, S. Lurie, C. H. Crisosto, and J. M. Labavitch, "Cell wall metabolism during the development of chilling injury in cold-stored peach fruit: association of mealiness with arrested disassembly of cell wall pectins," Journal of Experimental Botany, vol. 55, no. 405, pp. 2041-2052, 2004.

[39] R. P. Marini and J. R. Trout, "Sampling procedures for minimizing variation in peach fruit quality," Journal of the American Society for Horticultural Science, vol. 109, no. 3, pp. 361-364, 1984.

[40] G. Hale, J. Lopresti, E. Bonora, D. Stefanelli, and R. Jones, “Using non-destructive methods to correlate chilling injury with fruit maturity," in Proceedings of the 7th International Post-Harvest Symposium, Malaysia, 2012, Acta Horticolturae, March 2013.

[41] R. Infante, "Harvest maturity indicators in the stone fruit industry," Stewart Postharvest Review, pp. 1-6, 2012.

[42] T. M. DeJong and J. F. Doyle, "Leaf gas exchange and growth response of mature "Fantasia" nectarine trees to paclobutrazol," Journal of the American Society for Horticultural Science, vol. 109, pp. 878-882, 1984.

[43] R. Scorza, L. Zailong, G. W. Lightner, and L. E. Gilreath, "Dry matter distribution and responses to pruning within a population of standard, semidwarf, compact, and dwarf peach seedlings," Journal of the American Society for Horticultural Science, vol. 111, pp. 541-545, 1986.

[44] T. M. DeJong, K. R. Day, and J. F. Doyle, "The Kearney agricultural center perpendicular "V" (KAC-V) orchard system for peaches and nectarines," HortTechnology, vol. 4, no. 4, pp. 362-367, 1994.

[45] M. Forlani, B. Basile, C. Cirillo, and C. Iannini, "Effects of harvest date and fruit position along the tree canopy on peach fruit quality," Acta Horticulturae, vol. 2, pp. 459-466, 2002.

[46] G. Costa and G. Vizzotto, "Fruit thinning of peach trees," Plant Growth Regulation, vol. 31, no. 1-2, pp. 113-119, 2000.

[47] M. Faust, Physiology of Temperate Zone Fruit Trees, John Wiley \& Sons, New York, NY, USA, 1989.

[48] E. W. Pavel and T. M. DeJong, "Source- and sink-limited growth periods of developing peach fruits indicated by relative growth rate analysis," Journal of the American Society for Horticultural Science, vol. 118, no. 6, pp. 820-824, 1993.

[49] C. H. Crisosto, T. DeJong, K. R. Day et al., "Studies on stone fruit internal breakdown," in 1994 Research Reports for California Peaches and Nectarines, California Tree Fruit Agreement, Sacramento, Calif, USA, 1995. 


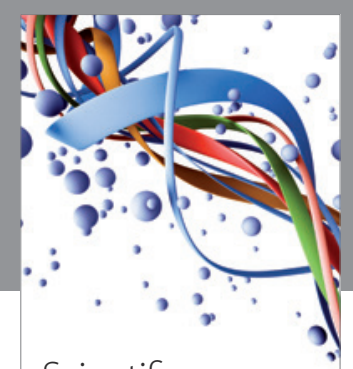

Scientifica
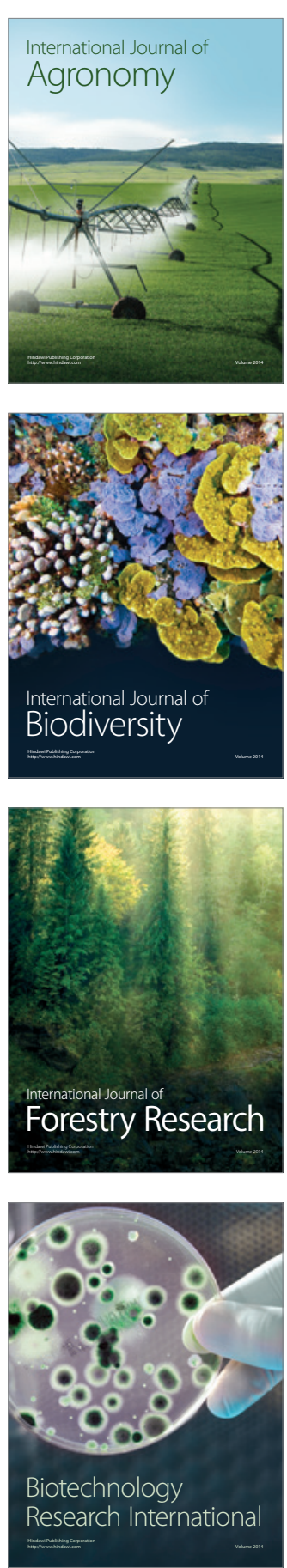
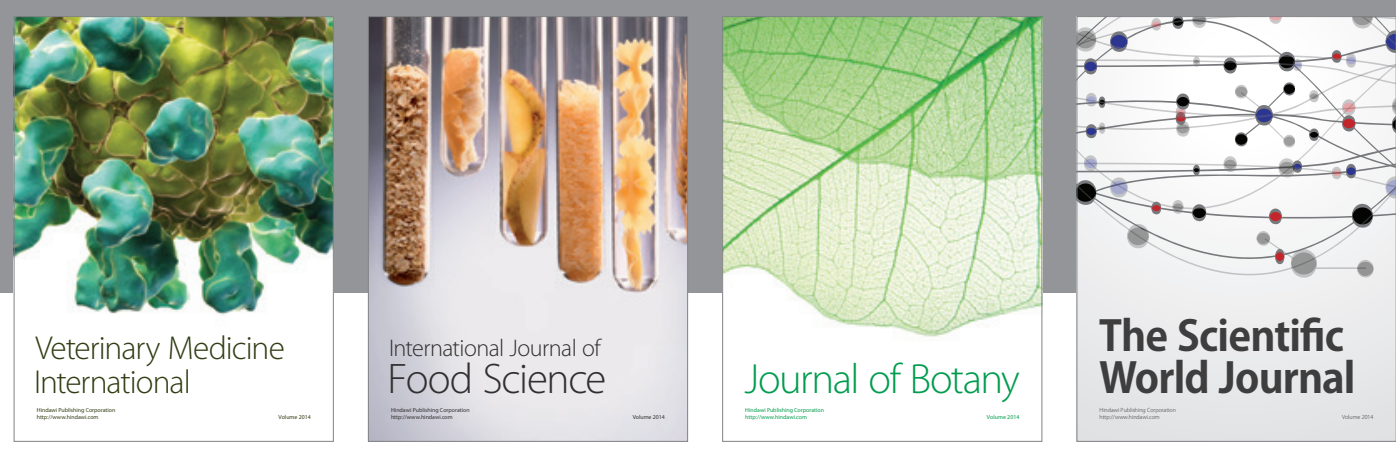

The Scientific World Journal
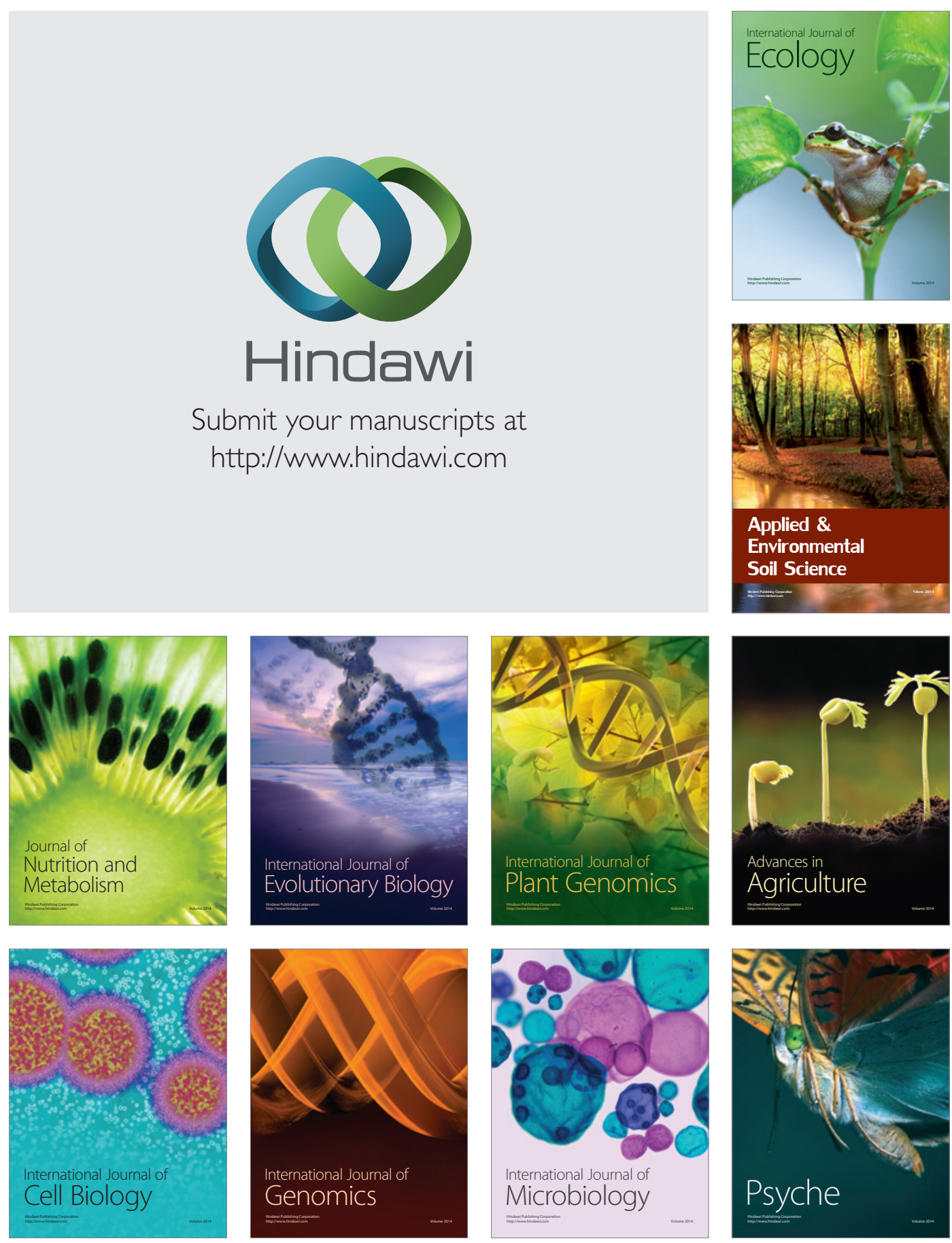